\title{
From DNA to consciousness - Crick's legacy
}

\section{Jonathan Knight}

Francis Crick, widely regarded as one of the twentieth century's most significant figures in biology, was a scientist to the end. In his hospital bed, just hours before he died on 28 July following a prolonged battle with colon cancer, he was working on a manuscript.

It was a theoretical discussion of the claustrum, a little-studied region of the brain that might play an important role in human consciousness, the object of Crick's academic efforts for nearly 30 years. His unending dedication to his work came as no surprise to friends and colleagues who spoke about him this week.

"He was the living incarnation of what it is to be a scholar," says Christof Koch, a computational neuroscientist at the California Institute of Technology in Pasadena and a close colleague of Crick's for 16 years. "He was always willing to revise his own views in light of the actions of a Universe that never ceased to astonish him."

Although Crick's name will forever be connected with the discovery of the doublehelix structure of DNA, which he published in 1953 with James Watson (Nature 171,
737-738; 1953), his subsequent contributions to molecular biology and neuroscience have also had a profound impact.

In the 1950s, he helped to prove that sequences of three bases in DNA code for particular amino acids, and described how these could be used to make proteins. Later he was instrumental in decrypting which triplets of bases coded for which amino acids.

By the mid-1970s, Crick's interest in

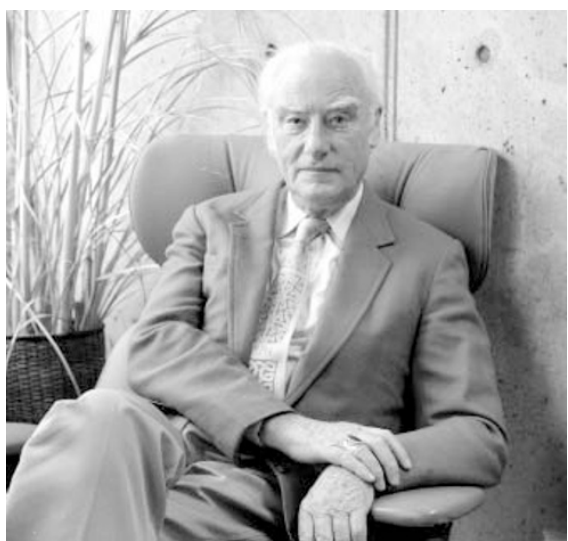

Francis Crick's unending dedication to science saw him working to the very end. molecular biology had begun to wane. He felt that the important problems had been solved, and that only details remained to be worked out."He didn't want to work on small problems," recalls Alexander Rich, a biologist at the Massachusetts Institute of Technology in Cambridge who solved the structure of one of the body's main structural proteins collagen - with Crick in 1955 (A. Rich and F. H.C. Crick Nature 176, 915-916; 1955).

In 1976, Crick moved to the Salk Institute for Biological Sciences in La Jolla, California, where he would devote the rest of his life to understanding the biological basis of consciousness - a problem many considered too difficult to tackle. "Because of his stature, he made brain science respectable," says Leslie Orgel, a colleague of Crick's at Salk.

The paper Crick was finishing when he died may influence the direction of Salk's Crick-Jacobs Center for Computational and Theoretical Biology, established earlier this year, says president Richard Murphy. "He thought the claustrum would be a good test system for the centre," Murphy says. The centre will focus on the genes, proteins and neural networks that make the brain function.

www.nature.com/nature/focus/crick

\section{'Militant' animal activists trigger British law change}

Jim Giles, London

"Exposed: mastermind of training camp for militants" read a front-page headline in the London Evening Standard last Wednesday. But this was not a story about al-Qaeda or political terrorists - the militants in question were animal-rights campaigners.

Animal-rights activists have led sometimes violent protests against biomedical research for more than a decade, particularly in Europe. But last week saw an upsurge in the attention paid to their campaigns in Britain, with the introduction of new laws against their protests and the announcement of fresh money for animal research.

Legislation unveiled on 30 July makes it illegal to mount protests that cause "harassment, alarm or distress" outside people's homes. Harassing a company's employees will also become an arrestable offence.

Such rules are seen as necessary by many scientists, given the history of animalrights activism in Britain. Over the past ten years, supporters of animal research have been attacked with baseball bats and had letter bombs posted to their homes. The Standard article claimed to reveal one person who was prepared to train "fanatics" in "unarmed combat" and "infiltration techniques" for future campaigns.

Recently, activists have focused their attention on plans for large, centralized research facilities. In January, one campaign contributed to the collapse of the University of Cambridge's plans for a new primate research centre. Similarly, on 19 July, building contractor Montpellier pulled out of work on an animal-research facility at the University of Oxford after attacks by

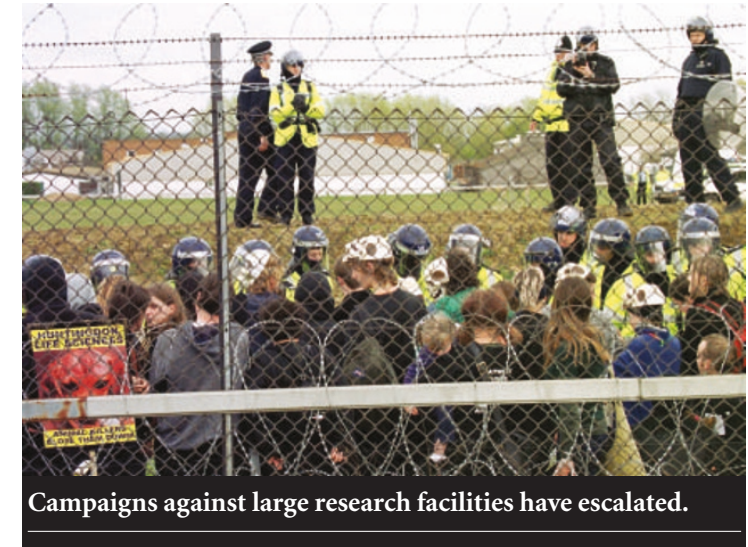

activists; the university insists that the project will go ahead.

In the same week as the new legislation, pharmaceutical companies pledged $\mathfrak{E} 4$ million (US\$7 million) over four years to fund animal research for medicines. The money pledged is small compared with the hundreds of millions spent in Britain each year on animal research, but scientists see it as a welcome gesture of support.

Observers say that both moves reflect a general change in public opinion. "People are increasingly aware of how our health depends on animal research," says Tipu Aziz, a neurosurgeon at the University of Oxford who is one of only a handful of researchers prepared to speak publicly in favour of animal research.

But lobbyists caution that it is not clear how successful the new legislation will be at deterring protests. This is the third set of such UK laws introduced since 2001, but the campaigners have proved adept at switching tactics to avoid prosecution, says Mark Matfield, executive director of the RDS, a London-based organization that lobbies in favour of animal research. "The government is focusing on protestors' tactics," says Matfield. "We need to look at making it an offence to organize these campaigns." 